\title{
Prevalence of Co Infection of Hepatitis B and Hepatitis C among HIV Seropositive Cases in a Tertiary Care Centre
}

\author{
Himabindu Mantravadi ${ }^{1}$ and B.Lakshmi ${ }^{2 *}$ \\ ${ }^{1}$ Department of Microbiology, Mallareddy institute of medical sciences, \\ Suraram, Hyderabad, Telangana, India \\ ${ }^{2}$ Department of Microbiology, MNR Medical College and Hospital, \\ Fasalwadi, Sangareddy, Telangana, India \\ *Corresponding author
}

\begin{tabular}{|c|c|}
\hline \multicolumn{2}{|r|}{ A B S T R A C T } \\
\hline & \multirow{8}{*}{$\begin{array}{l}\text { It is estimated that HIV and viral hepatitis infections are more common among the } \\
\text { developing countries. It is known that the progression of chronic HBV to cirrhosis, end- } \\
\text { stage liver disease, and/or hepatocellular carcinoma is more rapid in HIV-infected persons } \\
\text { than in persons with chronic HBV alone. This study was done to find out regional } \\
\text { prevalence of this co-infection and to take necessary steps to reduce morbidity, delay } \\
\text { mortality and improve quality of life in HIV/AIDS patients. Blood samples were collected } \\
\text { from } 3638 \text { patients, centrifuged and the serum was separated. This serum was screened by } \\
\text { immunochromatographic technique (card test for HBV and tridot for HIV and HCV). A } \\
\text { total of } 3638 \text { samples were studied, out of which } 3541 \text { were negative for all the three viral } \\
\text { infections. } 40 \text { were positive for HIV alone while } 51 \text { were positive for HBV and } 6 \text { were } \\
\text { positive for HCV. Only } 1 \text { sample showed positive for all } 3 \text { viruses, which accounted for } \\
0.02 \% \text { of the population, while } 3 \text { samples were found positive for both HIV and HBV } \\
\text { which amounts to } 0.08 \% \text { and no sample was positive for both HIV and HCV. Early } \\
\text { detection of the HIV and HCV must be done for all the HIV positive cases, so that } \\
\text { appropriate measures can be taken at the earliest. Further education of the population } \\
\text { regarding the transmission of the disease must be given to prevent the spread of the } \\
\text { disease. }\end{array}$} \\
\hline & \\
\hline & \\
\hline & \\
\hline & \\
\hline Article Info & \\
\hline & \\
\hline & \\
\hline
\end{tabular}

\section{Introduction}

The Human immunodeficiency virus (HIV) is a lentivirus that causes the Acquired immunodeficiency syndrome (AIDS), a condition in humans in which progressive failure of the immune system allows lifethreatening opportunistic infections and to thrive. Hepatitis B is an infectious illness of the liver caused by the Hepatitis $B$ virus (HBV) that affects apes, including humans. The acute illness causes liver inflammation, vomiting, jaundice and rarely, death. Chronic hepatitis B may eventually cause cirrhosis and liver cancer-a disease with poor response to all but a few current therapies. Hepatitis $\mathrm{C}$ is an infectious disease affecting primarily the liver, caused by the Hepatitis $\mathrm{C}$ virus (HCV). The infection is often asymptomatic, but chronic infection can lead to scarring of the liver and ultimately to cirrhosis, liver failure, liver cancer, or lifethreatening esophageal and gastric varices. It is estimated that HIV and viral hepatitis 
infections are more common among the developing countries and about one billion people are either exposed or are at risk (Brundtland, 2002; Fauci et al., 2012). About 34 million peple are estimated to be infected with HIV, 130 million with HCV and about 2 billion with HBV. Of them, 350-400 million people are said to be suffering from viral chronic hepatitis (Lu et al., 2009; Averhoff et al., 2012; Fauci et al., 2012; Javadi, 2014). 2 million people are estimated to die every year due to AIDS and 350 thousand die due to the diseases associated with $\mathrm{HBV}$ and $\mathrm{HCV}(\mathrm{Lu}$, 2009; Averhoff et al., 2012; UNAIDS, 2014).

Both HIV and HBV share the common modes of transmission, predominantly exposure to infectious blood or body fluids such as semen and vaginal fluids and high risk sexual activity. Other risk factors for developing these infections include working in a healthcare setting, transfusions, dialysis, sharing razors or toothbrushes with an infected person, travel in countries where it is common, and living in an institution.

It is less clear whether HCV, like the other two is sexually transmitted; it is more among the cases with history of intravenous drug use and blood transfusion. Hepatitis $\mathrm{B}$ and hepatitis $\mathrm{C}$ virus co-infections among HIV-1 infected individuals are a growing worldwide health problem characterized by lack of effective vaccines, need for expensive treatment, chronicity of morbidity and associated mortality (Lodenyo, 2000).

With the introduction of highly active antiretroviral therapy, there has been considerable reduction in the morbidity and the mortality of HIV patients (Alter, 2006). It is reported that the progression of the liver disease is three times more among the HIIV positive patient, than in non HIV patients (Soto et al., 1997; Mocroft et al., 2003; Vallet-Pichard et al., 2006). Conversely, chronic HBV does not substantially alter the progression of HIV infection (Yan-Heng Zhou et al., 2012). It is known that the progression of chronic HBV to cirrhosis, end-stage liver disease, and/or hepatocellular carcinoma is more rapid in HIV-infected persons than in persons with chronic HBV alone.

There is a lot of literature on the coinfection of HBV and HCV among the HIV patients from the developed countries and the western world, while the same in India is limited. Our geographical area is an industrial area, mainly populated by uneducated industrial laborers. The practices such as unprotected sex due to the ignorance of this population can cause the widespread transmission of HIV and co infections with $\mathrm{HBV}$ and HCV. This study was done to find out regional prevalence of this co-infection and to take necessary steps to reduce morbidity, delay mortality and improve quality of life in HIV/AIDS patients.

\section{Materials and Methods}

This study was conducted by the department of microbiology, Mallareddy Institute of Medical Sciences, from May, 2014 to September 2014. 3638 blood samples from blood donors and from patients with routine blood tests attending the OPD as well as the inpatients in Malla Reddy Institute of Medical Sciences were collected. These blood samples were centrifuged and the serum was separated.

This serum was screened by immunochromatographic technique (card test for $\mathrm{HBV}$ and tridot for $\mathrm{HIV}$ and $\mathrm{HCV}$ ). As per the normal protocol, if the samples were positive for HIV, they were confirmed by two other techniques i.e., comb's test an ELISA with fresh samples from the patients. Fresh samples were collected from the patients' positive for $\mathrm{HBV}$ and $\mathrm{HCV}$ and subjected to ELISA test for confirmation. 


\section{Results and Discussion}

Out of a total of 3638 samples studied, $3541(97.3 \%)$ were negative for all the three viral infections. 97 patients sera $(2.7 \%)$ were infected with at least one of these 3 viruses (Fig. 1).

Out of the 97 samples, 40 samples $(1.1 \%)$ were positive for HIV while 51 were positive for $\mathrm{HBV}(1.4 \%)$ and 6 were positive for $\mathrm{HCV}$ (0.2\%) (Fig. 2).

Only 1 sample showed positive for all 3 viruses, which accounted for $0.02 \%$ of the population, while 3 samples were found positive for both HIV and HBV which amounts to $0.08 \%$ and no sample was positive for both HIV and HCV (Fig. 3).
HIV and HCV, both of which are transmitted through the body fluids can remain in the blood stream for a long time before the appearance of the symptoms. A coinfection of $\mathrm{HCV}$ or HBV in HIV patients complicates the clinical course of the disease and may affect the proper treatment of HIV. This incidence is said to vary in different geographical regions.

A total of 3638 samples were studied, out of which 3537 were negative for all the three viral infections. 40 were positive for HIV while 51 were positive for $\mathrm{HBV}$ and 6 were positive for HCV. Only 1 sample showed positive for all 3 viruses, which accounted for $0.02 \%$ of the population, while 3 samples were found positive for both HIV and HBV which amounts to $0.08 \%$ and no sample was positive for both HIV and HCV.

Fig.1 Positive and negative reports of total sample

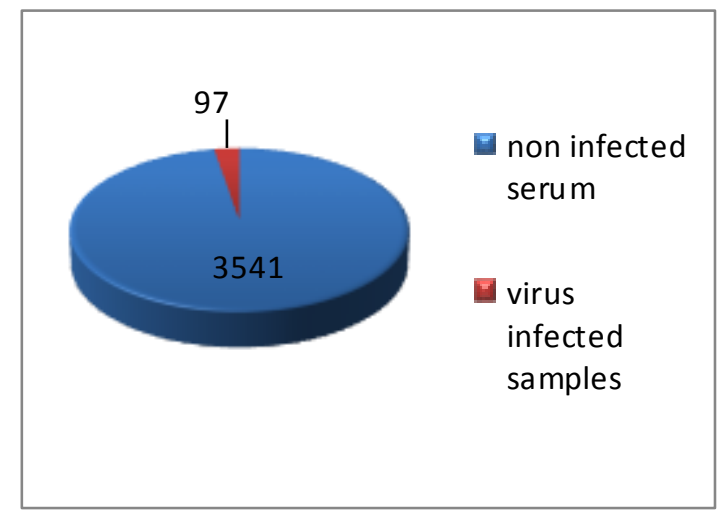

Fig.2 Prevalence of HIV, HBV and HCV in patients' sera

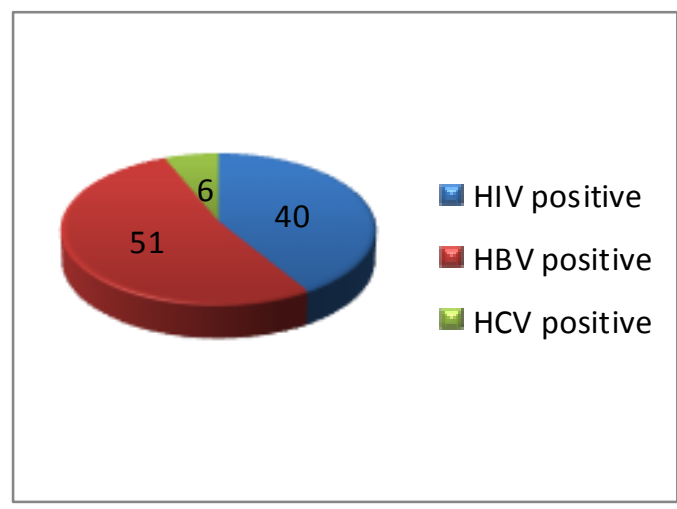


Fig.3 Coinfections seen in HIV positive patients

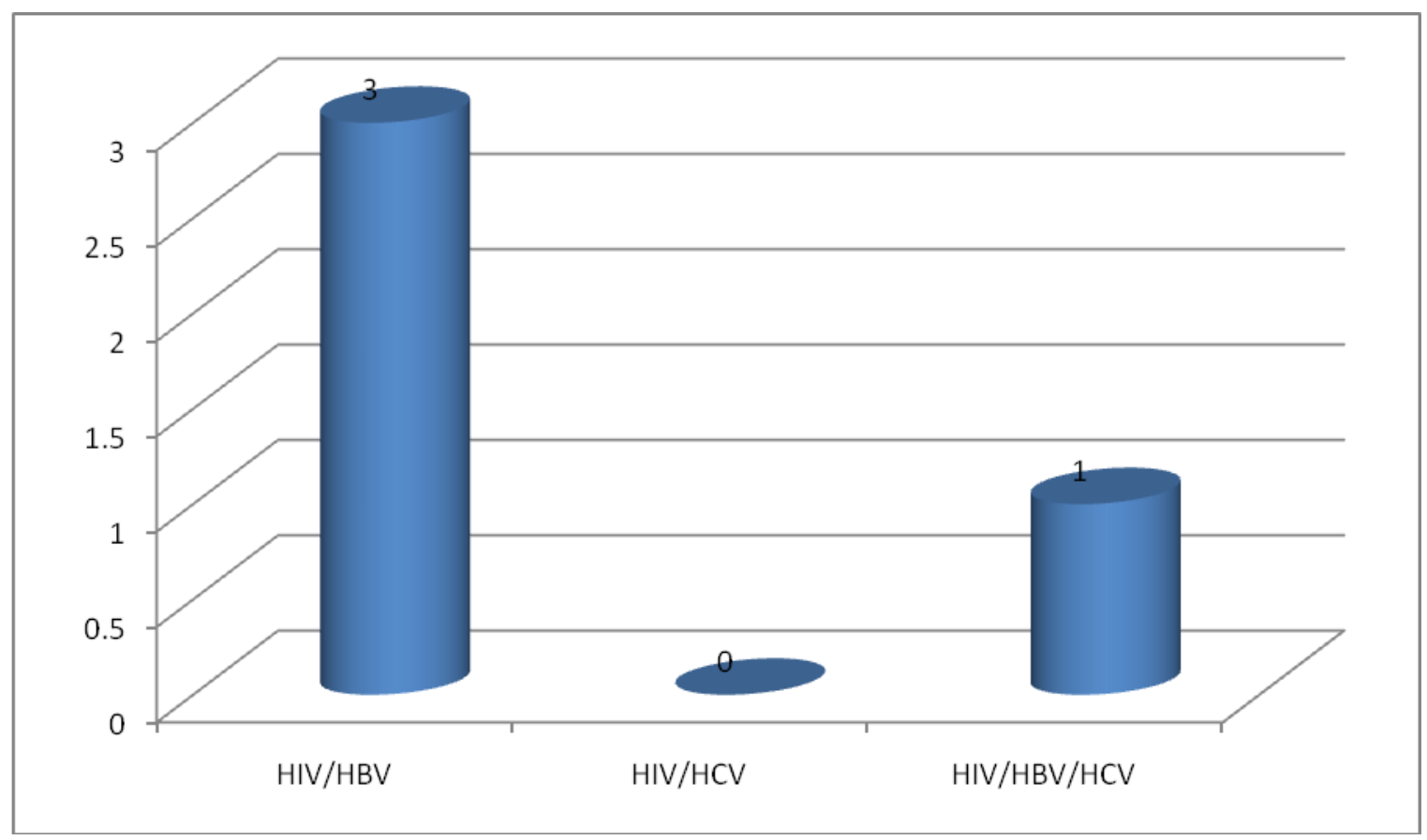

In our area, the prevalence of HIV alone was $1.1 \%$, HBV was $1.4 \%$ and $\mathrm{HCV}$ was $0.2 \%$. The prevalence of coinfection with HBV in HIV was $7 \%$ and $\mathrm{HCV}$ and HIV was $0 \%$. A coinfection of all the three viruses was $2.3 \%$ among the HIV positive patients.

In a study by Monga et al., (2001), out of 429 HIV positive patients, 166 were co infected with HCV. 263(61\%) were only HIV positive and 60 patients were $\mathrm{HCV}$ positive alone High morbidity and mortality $(6.8 \%)$ rates with decompensated liver disease were seen in co infected cases.

A very high prevalence of $\mathrm{HCV}$ and $\mathrm{HBV}$ coinfection of $50.3 \%$ was reported by Bùi Vũ Huy et al., (2014). A coinfection of all the three viruses was observed in $6.5 \%$ of the cases in this study.

Such high coinfection incidence was observed in other studies in China wherein $62.4 \%$ to 93.6\% was reported in intravenous drug users (Van et al., 2003; Quan et al., 2009), while in
Vietnam an incidence of $74 \%$ to $100 \%$ of coinfection was reported (Chen et al., 2013).

The prevelance of the coinfection in our country is also highly variable. In a study in Nagpur, the coinfection as observed in 30.4\% of the cases (Tankhiwale et al., 2003), while in Lucknow, it was around $2.2 \%$ (Tripathi et al., 2007). Further, in Chennai and Mumbai, it was found to be $7.7 \%$ and $3.5 \%$ respectively (Saravanan et al., 2007; Ahsan et al., 2002) 21, ${ }^{22}$. In the present study the incidence of coinfection among the HIV positive patients was $4.1 \%$. A study by found the coinfection of HIV and HBV to be $15 \%$ and $8.3 \%$ in HIV \& HCV coinfection (Chandra e al., 2013).

The general incidence of these sexually transmitted disease was much less than the other countries. It is possible as this is a semi suburban area and the population here is comparatively knowledgeable regarding the mode of transmission of the disease. However, further education can be done to reduce the incidence further. 
Early detection of the HIV and HCV must be done for all the HIV positive cases, so that appropriate measures can be taken at the earliest. Further education of the population regarding the transmission of the disease must be given to prevent the spread of the disease. Vaccination against HBV should be encouraged.

\section{References}

Ahsan SM, Mehta PR. HIV, HBV and HCV co-infection study. Bombay Hospital J. 2002;3:5-7.

Alter MJ. Epidemiology of viral hepatitis and co-infection. J Hepatol. 2006;44(Suppl 1):S6-9

Averhoff FM, Glass N, Holtzman D (2012) Global burden of hepatitis C: considerations for healthcare providers in the United States. Clinical Infectious Diseases 55: S10-S15.

Brundtland GH (2002) Reducing risks to health, promoting healthy life. Jama 288: 1974.

Bùi Vũ Huy, Kanxay Vernavong, and Nguyễn Văn Kính, "HBV and HCV Coinfection among HIV/AIDS Patients in the National Hospital of Tropical Diseases, Vietnam," AIDS Research and Treatment, vol. 2014, Article ID 581021, 5 pages, 2014. doi:10.1155/2014/581021

Chen, X., J.-M. He, L.-S. Ding, G.-Q. Zhang, X.-B. Zou, and J. Zheng, "Prevalence of hepatitis $B$ virus and hepatitis $C$ virus in patients with human immunodeficiency virus infection in central China," Archives of Virology, vol. 158, no. 9, pp. 1889-1894, 2013.

Fauci AS, Folkers GK (2012) Toward an AIDS-free generation. Jama 308: $343-$ 344.

Fauci AS, Morens DM (2012) The perpetual challenge of infectious diseases. New England Journal of Medicine 366: 454
461.

H.Lodenyo, B.Schoub, R.Ally, S.Kairu, I.Segal. Hepatitis $\mathrm{B}$ and $\mathrm{C}$ virus infections and liver function in Aids patients at Chris Hani Baragwanath Hospital, Johannesburg. East Afr Med J.2000 Jan; 77(1):13-5.

Harpreet K. Monga, Maria C. RodriguezBarradas, Katharine Breaux, Kamran Khattak, Catherine L. Troisi, and Maria Velez and Boris Yoffe. Hepatitis C Virus Infection-related morbidity and mortality among patients with human immunodeficiency virus infection. CID 2001:33

Javadi A, Ataei B, Kassaian N, Nokhodian Z, Yaran M (2014) Co-infection of human immunodeficiency virus, hepatitis $\mathrm{C}$ and hepatitis $\mathrm{B}$ virus among injection drug users in Drop in centers. Journal of research in medical sciences: the official journal of Isfahan University of Medical Sciences 19: S17

Lu F, Zhuang H (2009) Management of hepatitis B in China. Chin Med J (Engl)122: 3-4.

Mocroft A, Monforte A, Kirk O, Johnson MA, Friis- Moller N, Banhegyi D, et al., Decline in AIDS and death rates in EuroSIDA study; an observational study. Lancet. 2003;362:22-9.

Naval Chandra, Nayana Joshi, Y.S.N. Raju, Ajit Kumar, and Vijay D. Teja. Hepatitis B and/or C co-infection in HIV infected patients: A study in a tertiary care centre from south India. Indian J Med Res. 2013 Dec; 138(6): 950-954.

Quan, V. M., V. F. Go, L. V. Nam et al., "Risks for HIV, HBV, and HCV infections among male injection drug users in northern Vietnam: a casecontrol study," AIDS CarePsychological and Socio-Medical Aspects of AIDS/HIV, vol. 21, no. 1, pp. 7-16, 2009 
Sarvanan S, Velu V, Kumarswamy N, Nandkumar S, Murugavel KG, Balakrishnan $\mathrm{P}$, et al., Co-infetion of hepatitis B \& hepatitis C in HIV infected patients in South India. World J Gastroenterol. 2007;13:5015-20.

Soto B, Sanchez Quijano A, Rodrigo L, del Olmo JA, García-Bengoechea $\mathrm{M}$, Hernández-Quero J. Human immunodeficiency virus infection modifies the natural history of chronic parentally acquired hepatitis $\mathrm{C}$ with an unusually rapid progression to cirrhosis. J Hepatol. 1997;26:1-5.

Tankhiwale SS, Khadase RK, Jalgaonkar SV. Seroprevalence of anti $\mathrm{HCV}$ and hepatitis B surface antigen in HIV infected patients. Indian J Med Microbiol. 2003;21:268-70.

Tripathi AK, Khanna M, Gupta N, Chandra M. Low prevalence of hepatitis B virus and hepatitis $\mathrm{C}$ virus co infection in patients with human immunodeficiency virus in Northern India. J Assoc Physicians India. 2007; 55:429-31.

UNAIDS (2014) Islamic Republic of Iran
AIDS Progress Report On Monitoring of the United Nations General Assembly Special Session on HIV and AIDS.

Vallet-Pichard A, Pol S. Natural history and predictors of severity of chronic hepatitis $\mathrm{C}$ virus (HCV) and human immunodeficiency virus (HIV) coinfection. J Hepatol. 2006;44:528-34.

Van, V. T., N. T. Ha ^.nh, N. X. Quang, N. N. Điệp, and L. K. Tram, "Preliminary studies on co-infection of hepatitis B virus, ` hepatitis $\mathrm{C}$ virus in patients with HIV (+) at Bach Mai Hospital," Proceedings of Scientific Research Works in Bach Mai Hospital 20012002, pp. 471-478, 2003

Yan-Heng Zhou, Zhi-Hong Yao, Feng-Liang Liu, Hong Li, Li Jiang, Jia-Wu Zhu, Yong- Tang Zheng. High Prevalence of HIV, HCV, HBV and Co-Infection and Associated Risk Factors among Injecting Drug Users in Yunnan Province, China. PLoS ONE 7(8): e42937.

doi:10.1371/journal.pone.0042937

\section{How to cite this article:}

Himabindu Mantravadi and Lakshmi, B. 2017. Prevalence of Co Infection of Hepatitis B and Hepatitis C among HIV Seropositive Cases in a Tertiary Care Centre. Int.J.Curr.Microbiol.App.Sci. 6(12): 260-265. doi: https://doi.org/10.20546/ijcmas.2017.612.032 